\section{Contemporary conversations on authorship in Applied Linguistics: a literature review}

Conversações contemporâneas sobre autoria em linguística aplicada: uma revisão de

\author{
Ana Paula Carvalho SCHMIDT (UFSM) \\ ana-gcarvalho@hotmail.com \\ Desirée MOTTA-ROTH (UFSM) \\ mottaroth@gmail.com. \\ literatura

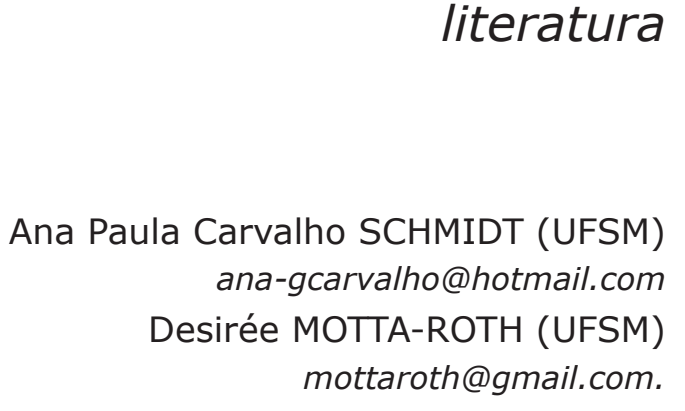

\title{
00000000000
}


Resumo: A atribuição de autoria tem sido uma preocupação em várias disciplinas, da Ciência da Informação (MIRANDA et al, 2007; VANZ; STUMPF, 2010) à Medicina (GRIEGER, 2005; MONTEIRO, 2004; PETROIANU, 2002). Nesse sentido, nosso objetivo neste trabalho é fornecer um panorama das Conversações (GEE, 1999) sobre autoria no campo da Linguística Aplicada de 2012 a 2015. Com base na Análise Crítica do Discurso (FAIRCLOUGH, 1992, 2003), revisamos nove artigos publicados em reconhecidos periódicos de Linguística Aplicada. Os resultados indicam que há quatro diferentes perspectivas a partir das quais autoria tem sido abordada: dialogismo, responsabilidade, posição ideológica e propriedade intelectual. Citação e paráfrase foram as práticas mais citadas em associação com o conceito de dialogismo como forma de exercício da autoria no contexto acadêmico.

Palavras-chave: Autoria. Letramentos acadêmicos. Linguística Aplicada.

\section{Introduction}

In the last decade, scientific productivity has become the main indicator of higher education quality, both in terms of institution and faculty reputation. Within this scenario, funds for research, tenure track positions, scholarships, and academic recognition are some of the factors that motivate researchers to produce and publish an increasing number of scientific publication. In the academic sphere, however, intellectual authorship seems to be a controversial point (CARNEIRO et al., 2007; HOWARD, 1995; PETROIANU, 2002), mainly regarding the setting of criteria for deciding to whom it should be attributed (CARNEIRO et al., 2007; GARCIA et al., 2010; GRIEGER, 2005; MONTEIRO et al., 2004; PETROIANU, 2002; WITTER, 2010).

Because it involves questions of identity and power relations, authorship attribution becomes an issue for discussion in current academic practices. Thus, the aim of this paper is to provide an overview on the Conversations (GEE, 1999) about authorship in the field of Applied Linguistics from 2012 to 2015. By exploring issues related to intellectual responsibility, attribution, collaborative writing and literacy practices, this paper aims at contributing to the umbrella project "Letramento acadêmico/científico e participação periférica legítima em comunidades de produção de conhecimento" (MOTTA-ROTH, 2013), whose research team is dedicated to the study of academic literacies as discursive and social practices, i.e., activities in which people get involved when living their social lives (MEURER, 2004, p. 138).

The term Conversations, as proposed by Gee (1999, p. 13), refers to "long-running and important themes or motifs that have been the focus of a variety of different texts and interactions (...) through a significant stretch of time and across an array of institutions." In 
v. 7 (2)

604-621

ago/dez 2017

our umbrella project, we recontextualize this term to refer to current theoretical discussions held in the literature of a given scientific area about a specific topic.

In this paper, we aim at exploring the topic of authorship practices as treated in a corpus of recent Applied Linguistics research articles by answering the following questions in order to identify the main themes or Conversations emerging from the data: a) How is authorship conceived by the authors examined in our study? b) What are the attributes associated with authorship in these research papers in the corpus? and c) How is authorship exercised according to these authors?

In order to discuss authorship in recent research, we have organized this paper in three sections. In Section 1, we briefly present three main concepts that constitute the theoretical framework. The methodology adopted in our study is described in Section 2. Next, in Section 3, we compare the articles that constitute the corpus in relation to how their authors conceive authorship. In the final section, we offer concluding remarks by pointing out that dialogicity and ethical awareness seem to be pervasive features in the various conceptualizations of authorship proposed in the published work we have analysed.

\section{Theoretical framework}

In this section, we will present definitions for the concepts of academic authorship, academic literacies and legitimate peripheral participation, which are central to our discussion of authorship.

\section{Academic Authorship}

When discussing the scientific field, Bourdieu (2004) claims that "the 'pure' universe of even the 'purest' science is a social field like any other, with its distribution of power and its monopolies, struggles and strategies, interests and profits, but it is a field in which all these invariants take on specific forms" (2004, p. 31). A constitutive part of these power struggles and strategies is the dispute around the attribution of authorship, which varies between the undue inclusion and exclusion of participants in the process of writing a scientific paper for publication. Participation in data collection, equipment borrowing to produce the results, or being a well-known researcher, which would increase the chance of acceptance for publication are some of the reasons 
to offer authorship to someone who in fact has not given substantial contribution to the work as a whole (CARNEIRO et al., 2007; GARCIA et al., 2010; MONTEIRO et al., 2004). On the other hand, the erasure of an author's name may occur due to personal misunderstanding among researchers (CARNEIRO et al., 2007; MONTEIRO et al., 2004), lack of interest in research by the student after defending a thesis or a dissertation, or change of research group.

As a result of this ethical dilemma, some researchers (PETROIANU, 2002; WITTER, 2010), especially in healthcare areas, have suggested a set of criteria to quantify the various actions involved in the attribution of authorship in a scientific paper. In Medicine, for example, Petroianu (2002) proposed a quantification of actions involved in the elaboration of a scientific article. The range of quantification varies from actions such as conceiving the whole project, defining and supporting the main hypothesis or interpretation of data to participation in the research routine without enough intellectual contribution to take public responsibility for the work. Petroianu suggests that a member of the research team will only get authorship if he/she sums up at least 7 points.

In the same line of thought, a similar set of quantitative criteria has been developed by Witter (2010) for assigning authorship in academic/ scientific articles. It should be noted, however, that there are slight differences in terms of scoring. Participation in writing the manuscript is worth 4 points in Witter's study and 5 points in Petroianu's table. Offering important suggestions regarding the manuscript and solving essential problems in the writing process are worth 3 points each in Witter's study while in Petroianu's table they are both worth 4 points. Advising the writing of the article and preparing the oral presentation are worth 2 points each in Witter's study and 3 points each in Petroianu's table. Obtaining funds and materials is worth 3 points in Witter's study and 2 points in Petroianu's table. Obtaining resources from funding agencies to purchase equipment and material for a project, in spite of involving little intellectual contribution, is a fundamental task in the process of writing a paper for publication according to Witter's framework. Thus, we conclude that Petroianu's system validates intellectual participation substantially more than Witter's.

These criteria were created based on the routines of production in the healthcare field, but deciding what action counts as relevant contribution for writing a paper varies from one area to another. By 
v. 7 (2)

604-621

ago/dez 2017 extension, the definition of authorship is "subject to several and even diverging interpretations at the level of concept and practice" (MIRANDA et al., 2007, p. 35).

The author of a scientific paper has been variously defined as: the subject who takes more intellectual responsibility for research design, contributing with ideas (PETROIANU, 2005; KERBAUY, 2005); "the one who reads, selects and analyzes previous, shared and established knowledge agreed by a scientific community" (CHRISTOFE, 1996, p. 12); or to whom credit and responsibility for what is written are attributed (HOEY, 2000). Garcia et al. (2010) and Miranda et al. (2007) suggest that authorship is an institution in crisis, pointing out that the concept of author itself should be reformulated. We assume the need to stimulate discussion on this topic in order to uncover assumptions about the prerogative of authorship.

A sense of authorship is developed through gradual participation in the activities system of a disciplinary community. An activity system is "any ongoing, object directed, historically conditioned, dialectically structured, tool-mediated human interaction" (RUSSELL, 1997, p. 510). To participate in the activity system of research, learning academic writing practices is a challenge to be faced. Academic writing has been approached through three models that will be described in the next section.

\section{Academic literacies}

Lea and Street (1998) carry out a case study in two British universities to identify and highlight different expectations of teachers and students in relation to written assignments. They identify three perspectives adopted in the teaching of academic writing: study skills, academic socialization and academic literacy.

In the study skills perspective, success in written production is viewed as a set of skills achieved through learning generic study skills without necessarily taking into account context peculiarities of each area of knowledge. This perspective in academic writing/teaching practices has been developed as a response to complaints that graduate students are not sufficiently well prepared for the job market (BASTALICH; BEHREND; BLOOMFIELD, 2014, p. 373).

The second approach to writing, the academic socialization perspective is based on social psychology, anthropology and constructivist 
education. In this perspective, the advisor is responsible for guiding students into the academic world. Students are supposed to construct an understanding of the dynamics of academic discursive practices, of what being a graduate student encompasses, and of the conventions that rule reading and writing in different fields of study. In the first chapter of her book Writing games: Multicultural case studies of academic literacy practices in higher education (2002, p.2), Casanave asserts that there is a common sense that "academic writing consists of rule and strategy-based practices". Thus, in order to become an active member in the academic context, academic socialization demands that students master these rules and strategies to participate in an increasing number of its writing practices.

Finally, the academic literacies approach emphasizes literacy as social practices. Student writing is seen as part of identity and the institutions in which these practices occur are seen as sites of discourse and power (LEA; STREET, 1998). This is a broader theoretical model in comparison to the study skills or the academic socialization approaches, but rather than mutually excluding or succeeding each other in a linear temporal dimension (LEA; STREET, 1998), the academic literacies model comprises features of both approaches. Academic literacies encompass academic social and discursive practices mediated by reading and writing. These practices are organized in genres that constitute the academic life, such as research project, abstracts for conferences, reviews and articles for publication and the graduation final work. Encouraging participation in the genres that pertain to this sphere of activity empowers students (COPE; KALANTZIS, 1993, p.7).

This assumption that participation in academic literacies practices creates a sense of authorship highlights the importance of the concept of Legitimate Peripheral Participation (LPP) (LAVE; WENGER, 1991; WENGER, 1998) as explained in the following section.

\section{Legitimate Peripheral Participation}

In their seminal book Situated Learning: Legitimate Peripheral Participation, Lave and Wenger introduce "a way of understanding learning" (1991, p.40), which emphasizes learning as participation of novice members in the sociocultural activities system of a professional community of practice toward their full participation in this system. Such process involves issues of construction of identities and unequal 
v. 7 (2)

604-621

ago/dez

2017

relations of power (LAVE; WENGER, 1991). The participation of novice members becomes legitimate insofar as they identify themselves as members of a particular community of practice, generating a sense of belonging. Yet it is considered peripheral due to the "multiple, varied, and more or less engaged ways of being located in the fields of participation defined by a community" (LAVE; WENGER, 1991, p. 36).

Their study reported five ethnographic researches in different communities of practice: midwives in Mexico, butchers and navy quartermasters in the United States, tailors in Liberia, and a group of nondrinking alcoholics. Although they do not focus on the school context specifically, they recognize that investigating the relation between school and communities where students live deserve consideration in research practices. In this paper, we recontextualize the concepts of Community of Practice (CoP) and Legitimate Peripheral Participation (LPP) in higher education due to our argument that, in addition to classroom interaction, the development of academic literacies and, consequently, authorship, depends on the legitimate and effective participation in a given CoP (MOTTA-ROTH, 2013), including "an increasing understanding of how, when, and about what old-timers collaborate, collude, collide, and what they enjoy, dislike, respect and admire" (LAVE; WENGER, 1991, p. 95). Old-timers refer to more experienced members in a CoP, such as advisors, more experienced graduate or undergraduate students who act and interact on different levels of participation, which correspond to how long and how engaged they are in the practices of a group.

\section{Methodological approach}

This section is organized as follows: a) universe of analysis, b) data collection and corpus of analysis, and c) procedures of analysis and interpretation.

Universe of analysis

The starting point of this bibliographic research was the Foundation for the Coordination of Graduate Training for Higher Education Faculty (CAPES) database ${ }^{1}$. The selection of journals was

\footnotetext{
${ }^{1}$ It publishes the official ranking of national and international journals for the Brazilian context. It classifies publications in eight levels: A1, A2, B1, B2, B3, B4, B5 and C. Available at: <http://www.capes.gov.br/avaliacao/instrumentos-de-apoio/ classificacao-da-producao-intelectual>.
} 
based on the following criteria: 1) ranked by CAPES as A1 and A2, 2) identified in the section labeled "About the Journal" as belonging to the field of Applied Linguistics studies, 3) language (contents in English and Portuguese only), and 4) free access. Rank criteria was adopted to select well-regarded journals in Applied Linguistics and resulted in the selection of seven titles: Bakhtiniana: Revista de Estudos do Discurso, D.E.L.T.A - Documentação em Estudos de Linguística Teórica e Aplicada, Revista Brasileira de Linguística Aplicada (RBLA), Trabalhos em Linguística Aplicada (TLA), Calidoscópio, Signo and Veredas.

Corpus selection

We selected articles: a) published from 2012 to 2015; b) that mentioned "author" or "authorship" and their respective translations to Portuguese in the title, abstract or keywords. Using these criteria, we identified 9 research articles, all of them written in Portuguese, as listed in Chart 1.

Chart 1 - References of selected research articles

\begin{tabular}{|c|l|}
\hline Code & \multicolumn{1}{c|}{ Article/Source } \\
\hline VER\#1 & $\begin{array}{l}\text { PEREIRA, Regina Celi Mendes; LEITÃO, Polyana Dayse Vasconcelos. } \\
\text { Apreensão do discurso de outrem e autoria em gêneros acadêmico- } \\
\text { científicos. Veredas online, Juiz de Fora, v. 19, n. 2, p. 195-208, 2015. }\end{array}$ \\
\hline BAK\#2 & $\begin{array}{l}\text { ARÁN, Pampa Olga. The question of the author in Bakhtin. } \\
\text { Bakhtiniana, Rev. Estud. Discurso, São Paulo, Número Especial, p. } \\
\text { 4-25, Jan./Jul. 2014. }\end{array}$ \\
\hline DELTA\#3 & $\begin{array}{l}\text { SILVEIRA, Ana Paula Kuczmynda da. Carnavalização e New Journalism: } \\
\text { O agenciamento da emoção e do ethos em crônicas da esfera } \\
\text { jornalística. DELTA, vol.30, no.2, p.181-196, 2014. }\end{array}$ \\
\hline RBLA\#4 & $\begin{array}{l}\text { ARAÚJO, Júlio César; DIEB, M. Authorship and deontology: mediation } \\
\text { of ethical principles and literacy practices in academic writing using a } \\
\text { virtual forum. RBLA, Belo Horizonte, v. 13, n. 1, p. 83-104, 2013. }\end{array}$ \\
\hline DELTA\#5 & $\begin{array}{l}\text { SALGADO, Luciana Salazar; GATTI, Márcio Antônio. Personagens } \\
\text { infantis de tiras cômicas em suportes diversos: uma questão de } \\
\text { circulação, aforização e estereotipia. DELTA, vol.29, no.spe, p.517- } \\
\text { 534, 2013. }\end{array}$ \\
\hline DELTA\#6 & $\begin{array}{l}\text { MORAES, Erika. Mona Lisa: sentidos múltiplos de um sorriso } \\
\text { enigmático. DELTA, vol. 29, no.Especial, p.443-465, 2013. }\end{array}$ \\
\hline RBLA\#7 & $\begin{array}{l}\text { ZART, Lídia Helena Muller; FRAGA, Dinorá Moraes de. Technology } \\
\text { tools for investigation of authorship. RBLA, Belo Horizonte, v. 13, n. 1, } \\
\text { p. 67-83, 2013. }\end{array}$ \\
\hline RBLA\#8 & $\begin{array}{l}\text { BERNARDINO, Cibele Gadelha. Academic article: interpersonal } \\
\text { meanings construction. RBLA, Belo Horizonte, v. 12, n. 3, p. 463-492, } \\
\text { 2012. }\end{array}$ \\
\hline RBLA\#9 & $\begin{array}{l}\text { FREITAS, Ana Beatriz Machado de. Enunciation and authorship } \\
\text { through alternative communication and dialogue mediation. RBLA, } \\
\text { Belo Horizonte, v. 12, n. 1, p. 165-180, 2012. }\end{array}$ \\
\hline
\end{tabular}


v. $7(2)$ 604-621 ago/dez 2017

After collecting the corpus, we proceeded with the textual analysis whose procedures are described in Section 2.3.

Data collection and text analysis procedures

We adopted the theoretical framework of Critical Discourse Analysis (FAIRCLOUGH, 1992, 2003) to interpret the role of lexical choices to construct the discourses on authorship. Fairclough (2003, p. 5) strongly suggests that the systemic functional approach (HALLIDAY; HASAN, 1989, p. 15; HALLIDAY; MATTHIESSEN, 2004, 2014) be adopted due to its focus on "(...) the relationship between language and other elements and aspects of social life (...)". Thus, in order to organize the data, the steps below were followed:

a) All the passages containing occurrences of the terms authorship, author, writing, text production, written discourse, academic/scientific production, academic genres were selected.

b) clauses were classified as participants, processes and circumstances.

\section{Results and discussion}

Our analysis will be presented in two parts. First, we will present central issues that guide the discussion on authorship in the analyzed articles. Secondly, we outline practices that are associated with authorship and academic writing.

How is authorship conceived and what are the attributes associated with it?

Academic writing practices present challenges for students and teachers who assist this process of transition from school to university, especially in terms of use of language "as a form of social practice" (FAIRCLOUGH; WODAK, 1997, p.258) in this new context. Example 1 illustrates that writing practices at university are regarded as a thorny path, mainly for undergraduate students. 
(1) RBLA\#4

\begin{tabular}{|c|c|c|c|c|}
\hline $\begin{array}{c}\text { O processo de } \\
\text { descoberta da } \\
\text { autoria }\end{array}$ & $\begin{array}{c}\text { por meio do } \\
\text { exercício da } \\
\text { pesquisa e } \\
\text { da escrita } \\
\text { de gêneros } \\
\text { acadêmicos }\end{array}$ & é & espinhoso & $\begin{array}{c}\text { para a maioria } \\
\text { dos alunos da } \\
\text { graduação. }\end{array}$ \\
\hline $\begin{array}{c}\text { Participant } \\
\text { (Carrier) }\end{array}$ & Circumstance & $\begin{array}{c}\text { Relational } \\
\text { process }\end{array}$ & $\begin{array}{c}\text { Participant } \\
\text { (Attribute) }\end{array}$ & Circumstance \\
\hline
\end{tabular}

Example 1 shows that a sense of authorship is not inherent knowledge, but it is gradually constructed insofar as students get engaged in a variety of written academic genres and get involved in concrete research practices.

Perhaps what makes academic writing practices challenging is that there is no uniform view about what authorship is or what it involves. At least four different elements that Applied Linguistics researchers associate with the construction of academic authorship were identified:

a) dialogicity (PEREIRA; LEITÃO, 2015; SILVEIRA, 2014; ARÁN, 2014; MORAES, 2013; ARAÚJO; DIEB, 2013): the author's recognition that his/her discourse is part of a historical chain of precedent discourses that constitute the body of knowledge of a specific scientific field.

b) responsibility (PEREIRA; LEITÃO, 2015; SALGADO; GATTI, 2013): it refers both to the prerogative to make choices and the duty of answering any questions about what is written, assuming an ethical attitude toward other discourses and in relation to participants in research.

c) ideological position (PEREIRA; LEITÃO, 2015; SILVEIRA, 2014; ARÁN, 2014; BERNARDINO, 2012): the author's attitude of agreement or disagreement in relation to precedent discourses and the articulation of his/her discourse in order to get readers' alignment.

d) intellectual property (ARÁN, 2014; SALGADO; GATTI, 2013; ZART, 2013): the publishing of a work, which may become a source of prestige for an individual.

In the following, we highlight each of these features, illustrating them with examples. 
v. 7 (2)

604-621

ago/dez

2017 a) Dialogicity

The first element, dialogicity, is rooted in the work of Bakhtin's Circle. Within this perspective, written discourse "responds to something, objects to something, affirms something, anticipates possible responses and objections, seeks support, and so on" (VOLOSINOV, 1973, p. 95). By constructing their argument, the author has responsibility for organizing the multiple voices of the polyphonic texts that constitute scientific production (ARAÚJO; DIEB, 2013, p.98). In this sense, authorship involves dialogue with both past and future publications. At the same time authors include a multiplicity of voices with which they may agree or disagree, they are also in a flux of discussion with their target audience (Example 2).

(2) DELTA\#3

\begin{tabular}{|c|c|c|}
\hline $\begin{array}{c}{[\ldots] \text { o próprio enunciado do }} \\
\text { autor }\end{array}$ & é & $\begin{array}{c}{[\ldots . .] \text { uma resposta a }} \\
\text { outros enunciados que o } \\
\text { antecedem [...] }\end{array}$ \\
\hline $\begin{array}{c}\text { Participant } \\
\text { (Carrier) }\end{array}$ & Relational process & $\begin{array}{c}\text { Participant } \\
\text { (Attribute) }\end{array}$ \\
\hline
\end{tabular}

Thus, the author is entitled to choose and adopt utterances to support their own perspective. At the same time, his own utterances are articulated to respond to previous ones.

In example 3, learning how to situate one's own work within the wider context of a scientific field is a prerequisite for participating effectively in the academic social practices mediated by language.

(3) RBLA\#4

\begin{tabular}{|c|c|c|c|}
\hline$[\ldots]$ um autor & deve & saber & $\begin{array}{c}\text { dialogar com as vozes de } \\
\text { outros pesquisadores [...] }\end{array}$ \\
\hline $\begin{array}{c}\text { Participant } \\
\text { (Senser) }\end{array}$ & - & $\begin{array}{c}\text { Mental process } \\
\text { (cognitive) }\end{array}$ & $\begin{array}{c}\text { Participant } \\
\text { (Phenomenon) }\end{array}$ \\
\hline
\end{tabular}

Departing from previous works is a feature of academic writing (SWALES; FEAK, 2000, p. 114). Offering readers an overview of a research topic is a strategy to claim the importance of the research being reported. 


\section{b) Responsibility}

The second feature of authorship mentioned in the literature is responsibility in relation to other authors' discourses and respect for intellectual property. Plagiarism is regarded as a crime. Therefore, giving credit to whom it is due is a way of being responsible. Besides ethical attitudes, researchers in our corpus suggest that the author should advance from a state of copying what others said to a state of assuming responsibility for and taking a stance towards what is quoted (Example 4).

(4) RBLA\#4

\begin{tabular}{|c|c|c|c|}
\hline $\begin{array}{c}\text { a ampliação da } \\
\text { consciência } \\
\text { deontológica que os } \\
\text { alunos constroem } \\
\begin{array}{c}\text { acerca do ato de } \\
\text { escrever, }\end{array}\end{array}$ & $\begin{array}{c}\text { de acordo com } \\
\text { as normas } \\
\text { estabelecidas e } \\
\text { praticadas pela } \\
\text { comunidade } \\
\text { acadêmica, }\end{array}$ & implica & $\begin{array}{c}\text { (...) a ampliação de } \\
\text { seus letramentos }\end{array}$ \\
\hline Participant (Identified) & Circumstance & $\begin{array}{c}\text { Relational } \\
\text { process }\end{array}$ & $\begin{array}{c}\text { Participant } \\
\text { (Identifier) }\end{array}$ \\
\hline
\end{tabular}

c) Ideological positioning

The third element that has been associated with authorship is ideological positioning, which is often closely related to a dialogical perspective.

(5) DELTA\#3

\begin{tabular}{|c|c|c|c|c|}
\hline $\begin{array}{c}\text { O conhecimento } \\
\text { que o autor tem do } \\
\text { outro, ou outros, } \\
\text { que constituem seu } \\
\text { auditório social, }\end{array}$ & orienta & $\begin{array}{c}-0 \\
\text { [o autor] }\end{array}$ & $\begin{array}{c}\text { para que se } \\
\text { posicione } \\
\text { discursiva e } \\
\text { ideologicamente } \\
\text { perante ele }\end{array}$ & $\begin{array}{c}\text { de maneira a } \\
\text { mobilizar nele } \\
\text { concordância, } \\
\text { adesão, } \\
\text { objeção, etc. ao } \\
\text { seu discurso. }\end{array}$ \\
\hline Participant (Actor) & $\begin{array}{c}\text { Material } \\
\text { process }\end{array}$ & $\begin{array}{c}\text { Participant } \\
\text { (Goal) }\end{array}$ & Circumstance & Circumstance \\
\hline
\end{tabular}

As suggested by Example 5, when authors write a manuscript for a journal, they have a specific readership in mind whom they intend to guide across the development of their particular ideas, either generating agreement or disagreement.

Example 6 points out that by choosing modal adjuncts of polarity and intensity, authors construct an axiological position toward the voices they include in their text. Lexical choices such as "not" and "very" are examples of this strategy. 
v. 7 (2)

604-621

ago/dez 2017

(6) RBLA\#8

\begin{tabular}{|c|c|c|c|}
\hline $\begin{array}{c}\text { [...] autores(as) } \\
\text { dos artigos } \\
\text { experimentais, } \\
\text { teóricos e de revisão }\end{array}$ & utilizaram & $\begin{array}{c}\text { o recurso da } \\
\text { negação e do grau } \\
\text { de intensificação } \\
\text { sobre o conteúdo } \\
\text { proposicional como as } \\
\text { duas estratégias mais } \\
\text { recorrentes }\end{array}$ & $\begin{array}{c}\text { para a } \\
\text { construção do } \\
\text { posicionamento } \\
\text { da autoria. }\end{array}$ \\
\hline Participant (Actor) & $\begin{array}{c}\text { Material } \\
\text { process }\end{array}$ & Participant (Goal) & Circumstance \\
\hline
\end{tabular}

d) Intellectual property

Finally, the concept of authorship has raised discussion about intellectual property. This view is grounded on the notion of individual intellectual creativity; it entails the right to profit and recognition (Example 7).

(7) BAK\#2

\begin{tabular}{|c|c|c|c|}
\hline [Isso] & [...] se trata de & $\begin{array}{c}\text { [...][uma } \\
\text { disputa] }\end{array}$ & $\begin{array}{c}\text { [sobre a diferença] entre } \\
\text { o patrimônio legal e o } \\
\text { intelectual. }\end{array}$ \\
\hline $\begin{array}{c}\text { Participant } \\
\text { (Carrier) }\end{array}$ & $\begin{array}{c}\text { Relational } \\
\text { process }\end{array}$ & $\begin{array}{c}\text { Participant } \\
\text { (Attribute) }\end{array}$ & Circumstance \\
\hline
\end{tabular}

Dialogicity seems to be the most essential element involved in the construction of authorship as it has been discussed in eight papers. To know what others have written before writing an academic genre, decide whether to engage with the ideas presented and learn how to quote properly are issues to be concerned with. These academic social practices also have implications on ethical aspects, such as plagiarism, "the most dangerous kind of appropriation in the sciences" (BIAGIOLI, 2012, p. 458).

Learning how to give credit and recognition when incorporating the ideas of others is one of the core concerns that arose in the discussions of almost all articles. Examples are given in the next section.

How is authorship exercised?

Writing the literature review or the results and discussion sections in a paper is an exercise of articulating discourses from other authors' texts. Therefore, properly referencing the sources on which the work is based minimizes the risk of unethical practices or even the risk of a lawsuit. Thus, quoting practices have been mentioned on a number of 
occasions in the literature. By removing some words from the passage quoted, students are omitting essential elements to the understanding of what is described. In Example 8, it is highlighted that, in scientific authorship, citation is a social practice. Therefore, students should be oriented on citation conventions and stimulated to practice it since their first year at university. Consequently, the author also benefits from citation. Being a highly cited professor, for instance, results in professional recognition and it may attract financial resources, such as scholarships, funding for developing projects, etc.

(8) RBLA\#7

\begin{tabular}{|c|c|c|c|}
\hline $\begin{array}{c}{[\ldots] \text { identificar a }} \\
\text { autoria de um texto }\end{array}$ & é & $\begin{array}{c}\text { uma prática } \\
\text { social }\end{array}$ & $\begin{array}{c}\text { como qualquer } \\
\text { outra que se } \\
\text { desenvolve através } \\
\text { da linguagem. }\end{array}$ \\
\hline Participant (Carrier) & Relational process & $\begin{array}{c}\text { Participant } \\
\text { (Attribute) }\end{array}$ & Circumstance \\
\hline
\end{tabular}

In example 9, the author argues that the choice of online content among the huge quantity of available information on the Web to write a text is a form of exercising authorship. She adds that citation is a social practice, and thus it is constructed.

(9) RBLA\#7

\begin{tabular}{|c|c|c|c|}
\hline $\begin{array}{c}\text { [...] [[quando ele [o aluno] } \\
\text { elabora um determinado trabalho, } \\
\text { usando os recursos do hipertexto, } \\
\text { os links, por exemplo, deixando } \\
\text { nele as marcas de sua caminhada, } \\
\text { selecionando pontos que vem ao } \\
\text { encontro de seus objetivos para } \\
\text { a construção de um determinado } \\
\text { sentido, }\end{array}$ & ele & $\begin{array}{c}\text { está } \\
\text { demarcando }\end{array}$ & $\begin{array}{c}\text { a sua } \\
\text { autoria]]. }\end{array}$ \\
\hline Circumstance & Participant & $\begin{array}{c}\text { Material } \\
\text { process }\end{array}$ & Goal \\
\hline
\end{tabular}

Within the contemporary academic scenario, new technologies have been considered initiators of new practices of authorship. However, the question of intellectual property arises again. Despite the efforts to create strategies to detect plagiarism, the internet is still a tool for those willing to deceive ethical rules (example 10). 
v. $7(2)$

604-621

ago/dez 2017
(10) RBLA\#4

\begin{tabular}{|c|c|c|c|}
\hline $\begin{array}{c}\text { O conteúdo da } \\
\text { internet }\end{array}$ & oferece & $\begin{array}{c}\text { amplo acesso } \\
\text { a textos } \\
\text { acadêmicos }\end{array}$ & $\begin{array}{c}\text { [[que podem } \\
\text { representar para } \\
\text { alunos desonestos uma } \\
\text { oportunidade de não } \\
\text { exercer sua autoria]]. }\end{array}$ \\
\hline Participant (Actor) & Material process & Goal & Projected clause \\
\hline
\end{tabular}

As pointed out before, plagiarism has been a constant concern in the articles reviewed and it seems that information technologies have enhanced the opportunities to copy and paste material without giving proper credit. Two authors recommend that school and undergraduate students receive guidance on avoiding scientific misconduct. The internet has been cited as a source and facilitator of students' unethical behavior when preparing an assignment.

\section{Conclusions}

In this paper, we reviewed nine articles published in wellregarded journals in the Applied Linguistics field. Although being a small-scale study, it indicates some trends in the area that may be best confirmed later by interviewing authors as part of our ethnographic research project.

By mapping the Conversations around the theme of authorship, our findings may be summarized in terms of the elements of authorship construction and the way in which authorship has been conceived in the Applied Linguistics field. Four different Conversations arose in the literature: dialogicity, ideological positioning, responsibility and intellectual property. Quoting and paraphrasing were the most cited practices in association with the concept of dialogicity as a form of exercising authorship in the academic context.

Four broad research themes were identified: a) authorship in the academic context (VER\#1, RBLA\#4, BAK\#2 and RBLA\#8); b) authorship in arts and media (DELTA\#3, DELTA\#5 and DELTA\#6); c) authorship in basic education (RBLA\#7); d) authorship and special education (RBLA\#9). In the academic scope, VER\#1 investigates levels of authorship in pre-service teachers' monographs. RBLA\# 4 analyses the use of a virtual forum to boost the learning of academic writing practices and to promote ethical awareness in undergraduate students. RBLA\#8 reports on how authors of academic/scientific articles in the Linguistics field construct an axiological positioning in their texts. 
The diversity of research themes and issues in the literature suggests that the role played by identity and power in the construction of academic authorship has not yet been sufficiently explored in the Applied Linguistics field. Following the academic literacies perspective (LEA; STREET, 1998), we argue that academic authorship dilemmas shall be explored in higher education practices, such as student writing in coauthorship with advisor for participating in conferences or for publication. Thus hidden and taken for granted norms, ethical behaviors, expectations and responsibilities shall be brought to light to give newcomers access to the multiple academic literacy social practices and dialogues.

\section{References}

ARÁN, P. O. The question of the author in Bakhtin. Bakhtiniana, Rev. Estud. Discurso, São Paulo, n. esp., p. 4-25, 2014.

ARAÚJO, J. C.; DIEB, M. Authorship and deontology: mediation of ethical principles and literacy practices in academic writing using a virtual forum. RBLA, Belo Horizonte, v. 13, n. 1, p. 83-104, 2013.

BASTALICH, W.; BEHREND, M.; BLOOMFIELD, R. Is non-subject based research training a "waste of time", good only for the development of professional skills? An academic literacies perspective. Teaching in Higher Education, Routledge: Londres, v. 19, n. 4, p. 373-384, 2014.

BERNARDINO, C. G. Academic article: interpersonal meanings construction. RBLA, Belo Horizonte, v. 12, n. 3, p. 463-492, 2012.

BIAGIOLI, M. Recycling texts or stealing time? Plagiarism, authorship, and credit in science. International Journal of Cultural Property, v. 19, n. 3, p. 453-476, 2012.

BORDIEU, P. The specificity of the scientific field and the social conditions of the progress of reason. In: BIAGIOLI, M. (Org.). The Science Studies Reader. New York: Routledge, 1999.

CARNEIRO, M. A.; CANGUSSÚ, S.; FERNANDES, W. Ethical Abuses in the Authorship of Scientific Papers. Revista Brasileira de Entomologia, v. 51, n. 1, p. 1-5, 2007.

CASANAVE, C. P. Writing games: Multicultural case studies of academic literacy practices in higher education. Mahvah, New Jersey: Lawrence Erlbaum, 2002.

CHRISTOFE, L. Intertextualidade e plágio: questões de linguagem e autoria. 1996. 193 f. Tese (Doutorado em Linguística) - Instituto de Estudos da Linguagem, Universidade Estadual de Campinas, Campinas, 1996.

COPE, B.; KALANTZIS, M. Introduction: how a genre approach to literacy can transform the way writing is taught. In: COPE, B.; KALANTZIS, M. (Orgs.). 
v. 7 (2)

604-621 ago/dez 2017

The powers of literacy: a genre approach to teaching writing. Pittsburgh, PA: University of Pittsburgh Press, 1993.

FAIRCLOUGH, N. Analysing discourse: textual analysis for social research. London, New York: Routledge, 2003.

Discourse and social change. Cambridge: Polity Press, 1992.

FAIRCLOUGH, N.; WODAK, R. Critical discourse analysis. In: VAN DIJK, T. A. (Org.). Discourse as social interaction. London: Sage, p. 258-284, 1997.

FREITAS, A. B. M. de. Enunciation and authorship through alternative communication and dialogue mediation. RBLA, Belo Horizonte, v. 12, n. 1, p. 165-180, 2012.

GARCIA, C. C. et al. Autoria em artigos científicos: os novos desafios. Revista Brasileira de Cirurgia Cardiovascular, v. 25, n. 4, p. 559-567, 2010.

GEE, J. P. How to do discourse analysis: a toolkit. New York: Routledge, 2011.

GRIEGER, M. C. A. Authorship: an ethical dilemma of science. São Paulo Medical Journal, v. 123, n. 5, p. 242-6, 2005.

HALLIDAY, M. A. K.; MATTHIESSEN, C. M. I. M. An introduction to Functional Grammar. 4th. ed. London: Edward Arnold, 2014.

An introduction to Functional Grammar. 3rd. ed. London: Hodder Education, 2004.

HALLIDAY, M. A. K.; HASAN, R. Language, context and text: aspects of language in a social-semiotic perspective. Oxford: Oxford University Press, 1989.

HOEY, J. Who wrote this paper anyway? The new Vancouver Group statement refines the definition of authorship. JAMC, v. 163, n. 6, p. 716-7, 2000.

HOWARD, R. M. Plagiarisms, authorships, and the academic death penalty. National Council of Teachers of English, v. 57, n. 7, p. 788-806, 1995.

KERBAUY, R. R. Autoria e coautoria: efeitos negativos e positivos. Estudos de Psicologia, Campinas, v. 22, n. 1, p. 89-94, 2005.

LAVE, J.; WENGER, E. Situated Learning: Legitimate Peripheral Participation. New York: Cambridge University Press, 1991.

LEA, M.; STREET, B. Student writing in higher education: an academic literacies approach. Studies in Higher Education. Abindgon, UK. V. 23, n. 2, p. 157-172, 1998.

MEURER, J. L. Ampliando a noção de contexto na Linguística SistêmicoFuncional e na Análise Crítica do Discurso. Linguagem em (Dis)curso, Tubarão, v. 4, n.esp, p. 133-157, 2004.

MIRANDA, A.; SIMEÃO, E.; MUELLER, S. Autoria coletiva, autoria ontológica e intertextualidade: aspectos conceituais e tecnológicos. Ciência da Informação, Brasília, v. 36, n. 2, p. 35-45, 2007. 
MONTEIRO, R. et al. Critérios de autoria em trabalhos científicos: um assunto polêmico e delicado. Revista Brasileira de Cirurgia Cardiovascular, v. 19, n. 4, 2004 .

MORAES, E. de. Mona Lisa: sentidos múltiplos de um sorriso enigmático. DELTA, v. 29, n. esp., p.443-465, 2013.

MOTTA-ROTH, D. Letramento acadêmico/científico e participação periférica legítima em comunidades de produção de conhecimento. Projeto de Pesquisa Bolsa PQ-CNPq no 309668/2013-1, 2013.

PEREIRA, R. C. M.; LEITÃO, P. D. V. Apreensão do discurso de outrem e autoria em gêneros acadêmico-científicos. Veredas online, Juiz de Fora, v. 19, n. 2, p. 195-208, 2015.

PETROIANU, A. Autoria de um trabalho científico. Revista da Associação Médica Brasileira, São Paulo, v. 8, n. 1, p. 60-65, 2002.

RUSSELL, D. Rethinking genre in school and society: An activity theory analysis. Written Communication, v. 14, n. 4, p. 504-554, 1997.

SALGADO, L. S.; GATTI, M. A. Personagens infantis de tiras cômicas em suportes diversos: uma questão de circulação, aforização e estereotipia. DELTA, v. 29, n. esp., p.517-534, 2013.

SILVEIRA, A. P. K. da. Carnavalização e New Journalism: O agenciamento da emoção e do ethos em crônicas da esfera jornalística. DELTA, v. 30, n. 2, p.181-196, 2014.

SWALES, J; FEAK, C. English in today's research world: a writing guide. Michigan: The University of Michigan Press, 2000.

VOLOSINOV, V. N. Marxism and the Philosophy of Language. Tradução: Ladislav Matejka and Irwin R. Titunik. London: Seminar Press, 1973 [1929].

WENGER, E. Communities of practice: learning, meaning, and identity. New York: Cambridge University Press. 1998.

WITTER, G. P. Ética e autoria na produção textual científica. Informação \& Informação, v. 15, n. esp., p. 131-144, 2010.

VANZ, S. A. de S.; STUMPF, I. R. C. Colaboração científica: revisão teóricoconceitual. Perspectivas em Ciência da Informação, v.15, n.2, p.42-55, 2010.

ZART, L. H. M.; FRAGA, D. M. de. Technology tools for investigation of authorship. RBLA, Belo Horizonte, v. 13, n. 1, p. 67-83, 2013.

Recebido em: 15 de fev. de 2017.

Aceito em: 29 de jul. de 2017. 